\title{
Deteksi Wajah dengan Berbagai Posisi Sudut pada Sekumpulan Orang dengan Membandingkan Metode Viola-Jones dan Kanade-Lucas-Tomasi
}

\author{
Aditya Pradana, Erick Paulus, Deni Setiana \\ Departemen Ilmu Komputer \\ Universitas Padjadjaran Bandung \\ aditya.pradana@unpad.ac.id, erick.paulus@unpad.ac.id, deni@unpad.ac.id
}

\begin{abstract}
Abstrak - Penelitian ini berisikan tentang sistem deteksi wajah pada gambar yang terdiri dari berbagai posisi wajah pada sekumpulan orang. Metode yang digunakan adalah KanadeLucas-Tomasi dan Viola-Jones. Metode Viola-Jones memiliki tingkat keakuratan cukup tinggi, di atas $90 \%$. Metode KanadeLucas-Tomasi juga memiliki tingkat keakuratan yang baik, namun membutuhkan waktu lebih lama untuk mendeteksi wajah dibandingkan metode Viola-Jones. Deteksi wajah diperlukan untuk mengetahui jumlah orang dalam sebuah kerumunan, karena bagian kepala biasanya terlihat dalam kerumunan yang penuh sesak. Data penelitian didapat dari hasil foto kegiatan di lab, kegiatan mahasiswa yang sedang ujian, dan kegiatan mahasiswa di kelas. Tujuan dari penelitian ini adalah untuk menentukan sudut yang masih bisa dianggap sebagai wajah dengan menggunakan metode Viola-Jones dan Kanade-LucasTomasi.
\end{abstract}

Katakunci - Viola-Jones; Kanade-Lucas-Tomasi; pengenalan wajah; posisi sudut gambar; sekumpulan orang;

Abstract - This research contains the face detection system on the image that consists of various positions in the face of a group of people. The method used is Kanade-Lucas-Tomasi and ViolaJones. Viola-Jones method has a fairly high degree of accuracy, above $90 \%$. Methods Kanade-Lucas-Tomasi also has a good degree of accuracy, but it takes longer to detect faces than Viola-Jones method. Face detection is required to determine the number of people in a crowd, because the head is usually seen in the crowd crowded. The research data obtained from the photo lab activities, student activities that are exams, and student activities in the classroom. The purpose of this study was to determine the angle that can still be regarded as the face using the Viola-Jones and Kanade-Lucas-Tomasi.

Keywords - Viola-Jones; Kanade-Lucas-Tomasi; face recognition; the angular position of images; group of people;

\section{Pendahuluan}

Penggunaan kamera bukan sekedar alat pelengkap saja, namun sudah menjadi alat utama dalam berbagai alat multimedia. Salah satu kegunaan yang utama dari kamera adalah sebagai alat untuk pengenalan wajah seseorang. Untuk mengenali wajah, harus mempunyai ketepatan dan kecepatan yang baik, sehingga dibutuhkan algoritma yang tepat.

Permasalahan yang sering muncul dalam pengenalan wajah diantaranya adalah belum adanya kesimpulan penggunaan metode terbaik untuk pengenalan wajah, serta kurangnya kecepatan dalam proses pengenalan wajah dan berapa sudut yang masih bisa ditoleransi dalam gambar citra orang. Beberapa penelitian tentang deteksi wajah pernah dilakukan. Banyak metode dan algoritma digunakan dalam pembangunan suatu perangkat lunak, seperti face recognition seperti Linear Discriminant Analysis (LDA), Independent Component Analysis (ICA), Principal Component Analysis (PCA).

Kar pada tahun 2012 melakukan penelitian tentang identifikasi biometrik wajah dengan metode Haar Cascade dan algoritma PCA eigenface [1]. Penelitian yang dilakukan Kar tersebut berhasil melakukan pengenalan wajah dengan sudut $0^{\circ}$ terhadap kamera dengan tingkat keakuratan 95\%.

Savitha dan Kumar pada tahun 2014 melakukan penelitian tentang face tracking dengan menggunakan S-PCA \& Metode KLT [2]. Hasil penelitian yang dilakukan Savitha dan Kumar adalah menemukan pendekatan baru dari S-PCA bersama dengan metode KLT dan digunakan untuk menggabungkan posisi dan emosi dari wajah.

Paul Viola dan Michael Jones pada tahun 2001 mengusulkan metode pendeteksian yang kemudian dikenal dengan metode Viola-Jones [3]. Metode Viola-Jones merupakan metode pendeteksian obyek yang memiliki tingkat keakuratan yang cukup tinggi yaitu 93,7\% dengan kecepatan 15 kali lebih cepat daripada metode Rowley Baluja-Kanade dan kurang lebih 600 kali lebih cepat daripada metode Schneiderman-Kanade [3].

Bagian II pada makalah ini memaparkan beberapa landasan teori yang mendukung penelitian ini. Bagian III menjelaskan cara kerja dari metode penelitian. Bagian IV menampilkan hasil eksperimen dari penelitian yang dilakukan dan simpulan dibahas pada bagian $\mathrm{V}$. 


\section{TEORI PENUNJANG}

\section{A. Biometrik}

Biometrik merupakan metode otomatisasi dari pengenalan seseorang berdasarkan sebuah karakteristik psikologi atau kelakuan [4]. Karakteristik yang harus dipertimbangkan dan dievaluasi pada teknologi biometrik diantaranya :

- Universality

- Uniqueness

- Permanence

- Collectibility

- Performance

- Acceptability

- Circumvention

Keuntungan menggunakan autentifikasi biometrik jika dibandingkan dengan metode konvensional adalah :

- Ketepatan akan bertambah, sehingga masalah yang sering terjadi seperti kehilangan kunci atau lupa kata kunci dapat dikurangi.

- Menambah keamanan, karena hanya ciri-ciri tertentu yang dimiliki seseorang tidak dimiliki oleh orang lain.

\section{B. Pengolahan Citra}

Citra (image) adalah gambar pada bidang dua dimensi yang merupakan fungsi continue dari intensitas cahaya [5]. Sumber cahaya menerangi objek, kemudian objek memantulkan kembali sebagian dari berkas cahaya tersebut. Pantulan cahaya ini ditangkap oleh alat-alat optik, misalnya mata pada manusia, kamera, pemindai (scanner), dan sebagainya, sehingga bayangan objek yang disebut citra tersebut terekam.

Citra dibagi menjadi dua jenis, yaitu citra diam dan citra bergerak. Contoh dari citra diam adalah gambar, sedangkan citra bergerak adalah video. Video merupakan rangkaian gambar (frame) yang ditampilkan secara beruntun, sehingga memberi kesan pada mata kita bahwa gambar tersebut bergerak. Pengolahan citra digital merupakan pemrosesan gambar dua dimensi dengan menggunakan komputer [6]. Citra digital merupakan larik yang berisi nilai-nilai real maupun komplek yang direpresentasikan dengan deretan bit tertentu.

Citra dapat didefinisikan sebagai sebuah fungsi $f(x, y)$ dengan $\mathrm{f}$ adalah amplitudo, $\mathrm{x}$ dan $\mathrm{y}$ adalah koordinat spasial, $\mathrm{M}$ baris dan $\mathrm{N}$ kolom. Bila nilai $\mathrm{x}$, $\mathrm{y}$, f secara keseluruhan berhingga dan bernilai diskrit, maka dapat disimpulkan bahwa citra tersebut adalah citra digital.

Terdapat tiga bidang studi yang berkaitan dengan dengan data citra yaitu [5] :

1. Grafika komputer (computer graphics)

Bertujuan menghasilkan cotra dengan primitif-primitif geometri seperti garis, lingkaran, kotak, dan sebagainya.

2. Pengolahan citra (image processing)

Bertujuan memperbaiki kualitas citra agar mudah diintepretasikan oleh manusia dan komputer
3. Pengenalan pola (pattern recognition)

Mengelompokkan data numerik dan simbolik secara otomatis agar mengenali objek dalam citra

\section{Deteksi Wajah}

Asumsi yang sering digunakan pada pengenalan wajah adalah wajah yang akan dikenali memiliki ukuran dan latar belakang yang sama. Walau pada keadaan nyata, hal tersebut sulit terjadi, karena ukuran, latar belakang, posisi, sudut akan berbeda-beda [7]. Pendeteksian wajah merupakan tahap awal yang sangat penting sebelum melakukan proses pengenalan wajah. Faktor-faktor yang dihadapi pada proses pendeteksian wajah yang sering terjadi diantaranya adalah posisi wajah (tegak lurus, miring, samping, dll), komponen wajah (kumis, jenggot, dll), ekspresi wajah (senyum, sedih, tertawa, dll), citra terhalang objek lain, kondisi lingkungan (cahaya, lensa kamera, dll). Penelitian-penelitian yang berkaitan dengan pemrosesan wajah diantaranya :

- $\quad$ Pengenalan wajah (face recognition)

- Autentifikasi wajah (face authentication)

- Lokalisasi wajah (face localization)

- Penjejakan wajah (face tracking)

- Pengenalan ekspresi wajah (facial expression recognition)

\section{Metode Viola-Jones}

Metode Viola-Jones merupakan metode yang paling banyak digunakan dalam proses pengenalan wajah. Metode Viola-Jones menggunakan data latih yang digunakan dalam proses pengklasifikasian citra. Klasifikasi citra dilakukan berdasarkan nilai dari sebuah fitur. Fitur-fitur ini merupakan gambaran dari wajah manusia yang biasa disebut sebagai Haar Feature [8].

Citra integral digunakan untuk menghitung fitur Haar. Proses dengan menggunakan fitur lebih cepat dibandingkan pemrosesan citra per piksel. Gambar 1 menampilkan tiga jenis fitur berdasarkan jumlah persegi panjang yang terdapat di dalamya [3]. A dan B terdiri dari dua persegi panjang, C terdiri dari tiga persegi panjang, dan $\mathrm{D}$ terdiri dari empat persegi panjang. Nilai fiturnya dapat dihitung dengan mengurangkan piksel pada area putih dengan piksel pada area hitam. Untuk mempermudah perhitungan digunakan integral image.
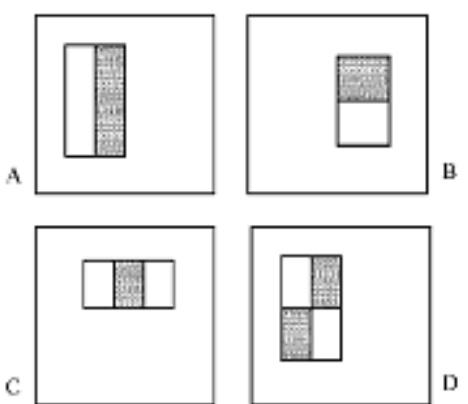

Gambar 1. Contoh fitur persegi panjang 
Integral image adalah citra dimana nilai tiap pikselnya merupakan penjumlahan dari nilai piksel kiri atas sampai dengan kanan bawah, seperti ditunjukkan pada Gambar 2.

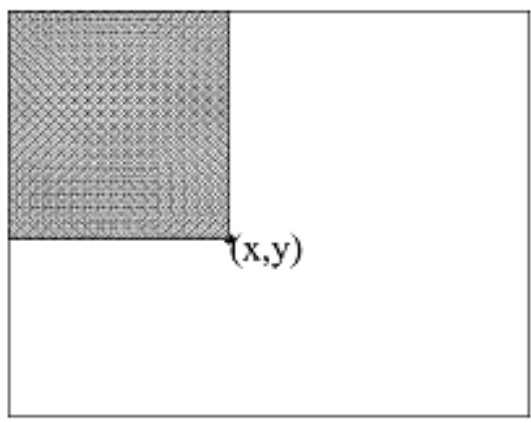

Gambar 2. Perhitungan integral image

Nilai rata-rata piksel pada area yang diarsis dapat dilakukan dengan perhitungan yang diperlihatkan pada Gambar 3.

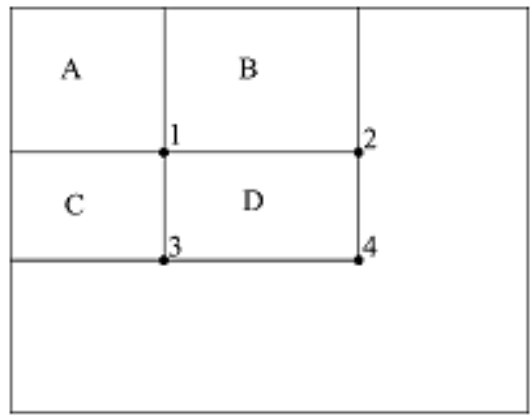

Gambar 3. Integral image

Nilai D didapat dengan cara menggabungkan jumlah piksel pada area segiempat $\mathrm{A}+\mathrm{B}+\mathrm{C}+\mathrm{D}$ kemudian dikurangi jumlah segiempat $\mathrm{A}+\mathrm{B}$ dan $\mathrm{A}+\mathrm{C}$ lalu ditambah dengan jumlah piksel pada $\mathrm{A}$. Sehingga nilai $\mathrm{D}$ dapat dihitung dengan rumus $\mathrm{D}=$ $(\mathrm{A}+\mathrm{B}+\mathrm{C}+\mathrm{D})-((\mathrm{A}+\mathrm{B})+(\mathrm{A}+\mathrm{C}))+\mathrm{A}$.

Untuk mendapatkan fitur yang memiliki nilai paling baik, Viola-Jones menggunakan metode machine learning yang disebut AdaBoost. AdaBoost menggabungkan classifier lemah yang hanya mendapatkan nilai true lebih sedikit sehingga menghasilkan classifier kuat [9]. Karakteristik algoritma Viola-Jones adalah adanya klasifikasi bertingkat, terdiri dari tiga tingkatan seperti diperlihatkan pada Gambar 4.

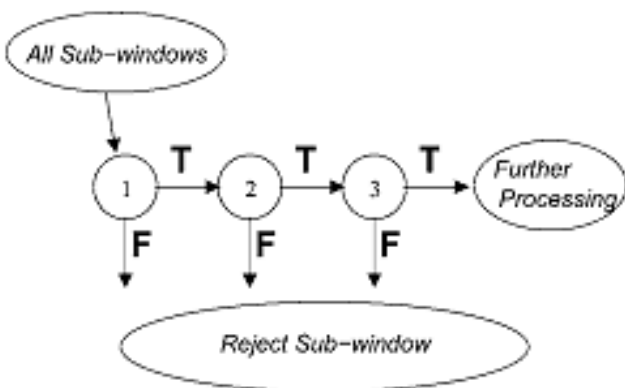

Gambar 4. Skema pendeteksian bertingkat
Tiap subcitra pada tingkat pertama diklasifikasikan menggunakan satu fitur. Jika memenuhi fitur Haar tertentu akan berninal true dan jika tidak akan bernilai false. Sisa klasifikasi sekitar 50\% akan kembali diklasifikasikan pada tahap ke dua. Hasil klasifikasi yang memenuhi proses integral image akan bernilai true dan jika tidak memenuhi akan bernilai false. Dengan bertambahnya tingkat klasifikasi dan syarat yang lebih spesifik, maka jumlah fitur akan semakin banyak, dan jumlah subcitra yang lolos klasifikasi akan berkurang hingga sekitar 2\% [3]. Gambar akan bernilai true jika memenuhi syarat AdaBoost, dan akan bernilai false jika tidak memenuhi syarat.

\section{E. Algoritma KLT (Kanade-Lucas-Tomasi)}

Optical Flow merupakan sebuah gerakan yang terlihat berdasarkan urutan cahaya pada citra secara sekuen. Pada suatu bagian citra, perubahan intensitas cahaya dapat disebabkan oleh pergerakan objek, sumber cahaya, maupun sudut pandang. Terdapat dua asumsi, yaitu :

- Brightness $I(x, y, t)$ bergantung pada koordinator $\mathrm{x}, \mathrm{y}$ yang ada dalam bagian yang lebih besar dari gambar.

- Brightness tiap titik pada objek bergerak yang tidak berubah terhadap waktu.

Tiga tahap dalam prinsip kerja algoritma Kanade-LucasTomasi dalam melacak titik fitur wajah adalah [10].:

- $\quad$ Ekstrasi titik fitur wajah (feature extraction)

- Memilih fitur wajah (feature selection)

- Melacak titik fitur wajah (feature tracking)

\section{MEtode PENELITIAN}

Untuk menentukan derajat kemiringan berapa saja yang masih dapat dikenali sebagai wajah, dilakukan pengambilan citra dengan beberapa sudut. Setelah gambar diambil dari berberapa sudut, gambar tersebut diuji dengan menggunakan metode Viola-Jones dan Kanade-Lucas-Tomasi. Kemudian dilihat hasilnya, apakah dapat dikenali sebagai wajah atau tidak. Jika dikenali sebagai wajah, maka akan diberi tanda. Jika tidak, maka gambar tersebut tidak akan ditandai apapun. Gambar 5 memperlihatkan alur pengenalan wajah yang dilakukan.

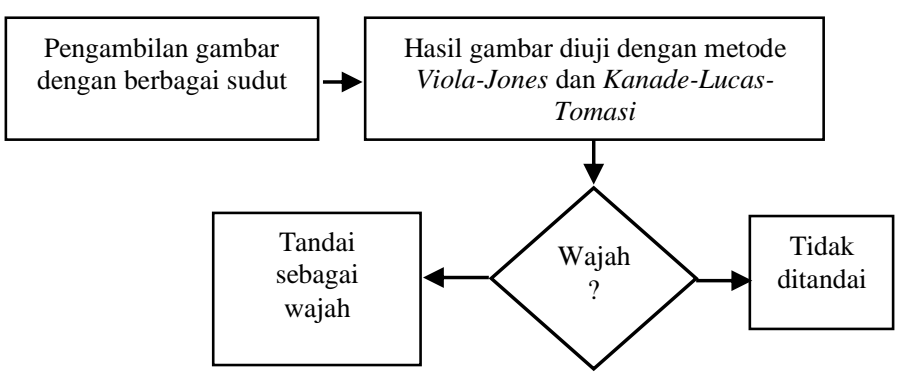

Gambar 5. Diagram alur pengenalan wajah 
Pada awalnya dibuatlah data ground truth untuk mengetahui sudut berapa saja yang masih bisa dikenali sebagai wajah. Ground truth dibuat dengan mengambil wajah satu orang dalam satu frame. Setelah diketahui sudut berapa saja yang masih dikenali sebagai wajah, gambar yang diuji selanjutnya adalah gambar yang terdiri dari sekumpulan orang.

\section{HASIL}

Gambar yang dipakai dalam penelitian ini adalah gambar kegiatan mahasiswa dan dosen baik di laboratorium, kelas, maupun di luar ruangan. Dalam satu gambar terdiri dari banyak orang dan banyak posisi. Pencahayaan pun dibuat sealami mungkin.

Gambar ground truth yang dibuat terdiri dari dua orang yang berbeda. Orang pertama tidak memakai kacamata, sedangkan orang ke dua memakai kacamata. Gambar 6 menunjukkan hasil pengenalan wajah orang pertama dengan menggunakan metode Viola-Jones dalam berbagai posisi sudut. Dari 9 gambar, yang terdeteksi sebagai wajah adalah 7 buah gambar, sisanya tidak dikenali sebagai wajah.

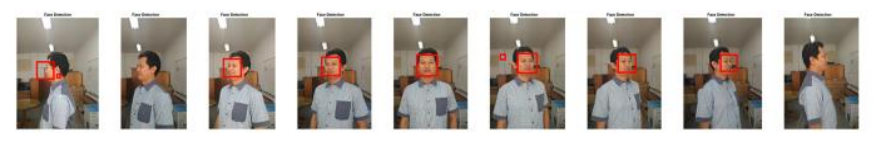

Gambar 6. Hasil pengenalan wajah orang pertama dengan metode Viola-Jones pada berbagai posisi sudut

Gambar 7 menunjukkan hasil pengenalan wajah orang pertama dengan menggunakan metode Kanade-Lucas-Tomasi dalam berbagai posisi sudut. Dari 9 gambar, yang terdeteksi sebagai wajah adalah 6 buah gambar, sisanya tidak dikenali sebagai wajah.

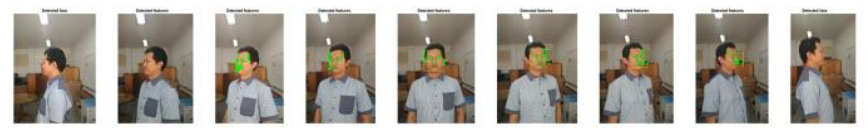

Gambar 7. Hasil pengenalan wajah orang pertama dengan metode KanadeLucas-Tomasi pada berbagai posisi sudut

Gambar 8 menunjukkan hasil pengenalan wajah orang ke dua dengan menggunakan metode Viola-Jones dalam berbagai posisi sudut. Dari 9 gambar, yang terdeteksi sebagai wajah adalah 4 buah gambar, sisanya tidak dikenali sebagai wajah.
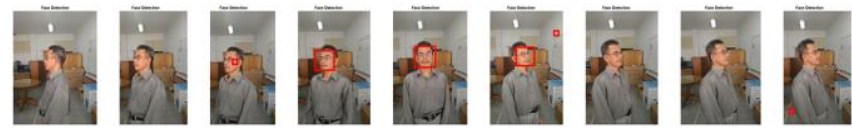

Gambar 8. Hasil pengenalan wajah orang ke dua dengan metode Viola-Jones pada berbagai posisi sudut

Gambar 9 menunjukkan hasil pengenalan wajah orang pertama dengan menggunakan metode Kanade-Lucas-Tomasi dalam berbagai posisi sudut. Dari 9 gambar, yang terdeteksi sebagai wajah adalah 4 buah gambar, sisanya tidak dikenali sebagai wajah.
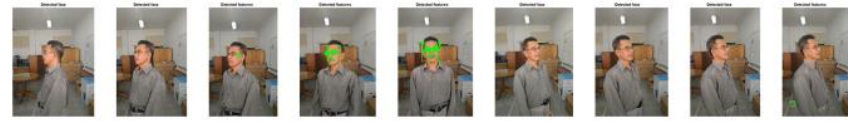

Gambar 9. Hasil pengenalan wajah orang ke dua dengan metode KanadeLucas-Tomasi pada berbagai posisi sudut

Data ground truth menunjukkan bahwa dengan menggunakan metode Viola-Jones, objek yang dikenali sebagai wajah lebih banyak daripada menggunakan metode KanadeLucas-Tomasi. Untuk sudut tegak lurus, dari dua kali percobaan, metode Viola-Jones sukses mengenali wajah sebanyak satu kali. Untuk metode Kanade-Lucas-Tomasi, kedua percobaan tidak mengenali objek sebagai wajah.

Gambar 10 menampilkan hasil pengenalan wajah dengan menggunakan metode Kanade-Lucas-Tomasi pada sekumpulan orang. Hasil dengan menggunakan metode Kanade-LucasTomasi dari 19 wajah, terdeteksi 18.

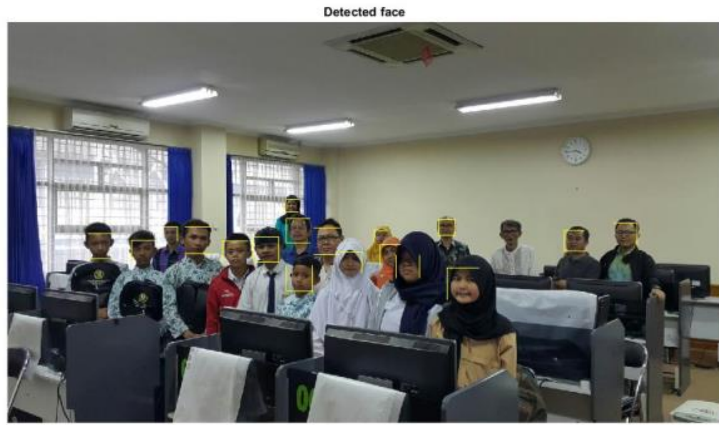

Gambar 10. Hasil pengenalan wajah orang pertama dengan metode KanadeLucas-Tomasi pada berbagai posisi sudut

Pada Gambar 11 dengan citra foto yang sama dengan Gambar 10, digunakan metode Viola-Jones dan menghasilkan 18 wajah terdeteksi dari total 19 wajah pada gambar. Gambar 12 menampilkan hasil pengenalan wajah dengan menggunakan metode Kanade-Lucas-Tomasi pada sekumpulan orang. Hasil dengan menggunakan metode Kanade-Lucas-Tomasi dari 27 wajah, hanya terdeteksi 7.

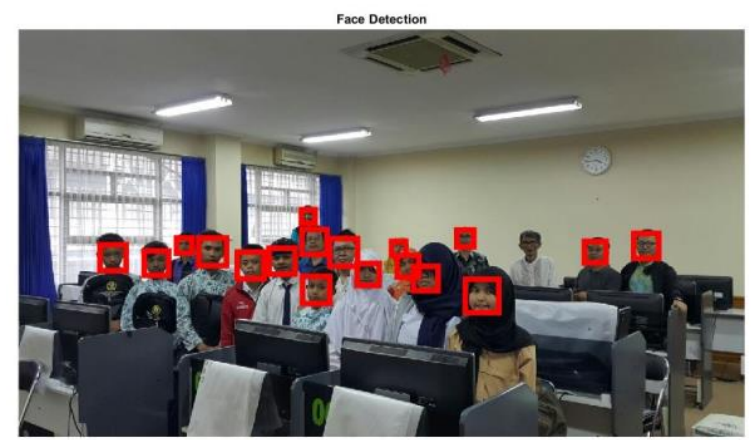

Gambar 11. Hasil pengenalan wajah orang pertama dengan metode Viola-Jones pada berbagai posisi sudut 
p-ISSN 2089-8673 | e-ISSN 2548-4265

Jurnal Nasional Pendidikan Teknik Informatika (JANAPATI)

Volume 5, Nomor 3, Desember 2016

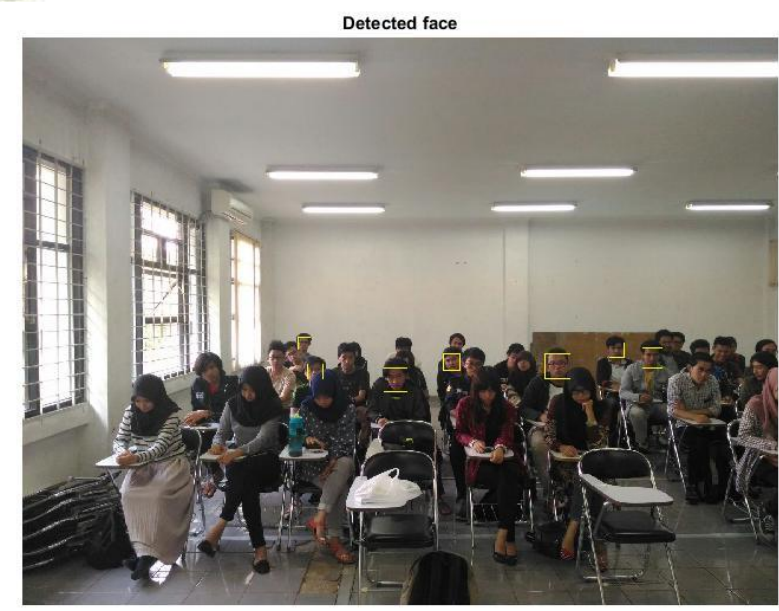

Gambar 12. Hasil pengenalan wajah orang pertama dengan metode KanadeLucas-Tomasi pada berbagai posisi sudut

Pada Gambar 13 dengan citra foto yang sama dengan Gambar 13, digunakan metode Viola-Jones dan hanya menghasilkan 7 wajah terdeteksi dari total 27 wajah pada gambar.

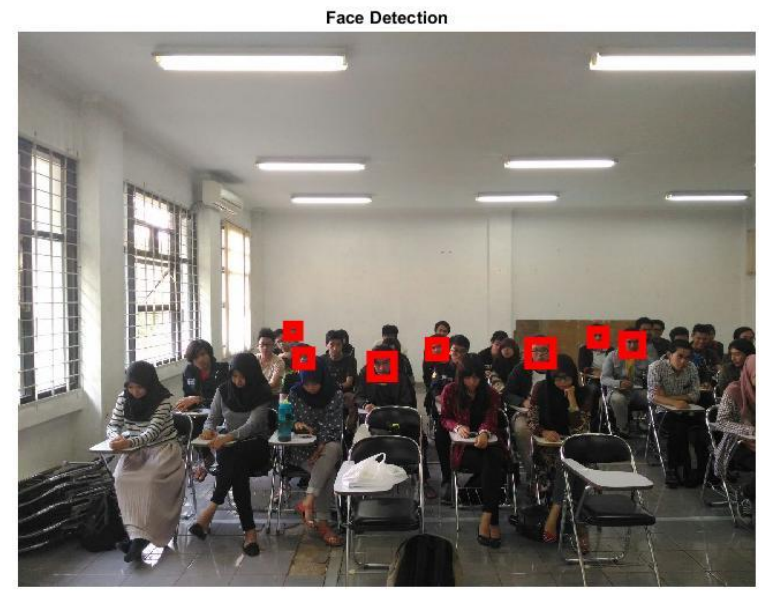

Gambar 13. Hasil pengenalan wajah orang pertama dengan metode Viola-Jones pada berbagai posisi sudut

Percobaan pengenalan wajah pada sekumpulan orang dengan menggunakan metode Kanade-Lucas-Tomasi secara lengkap menghasilkan data seperti yang tersaji pada Tabel I.

TABEL I. HASIL PERCOBAAN METODE KANADE-LUCAS-TOMASI

\begin{tabular}{|c|c|c|c|c|c|c|}
\hline \multicolumn{7}{|c|}{ Kanade-Lucas-Tomasi } \\
\hline Data & Hasil & Waktu & & Data & Hasil & Waktu \\
\hline 1 & $83,33 \%$ & 2,81 & & 18 & $7,14 \%$ & 1,64 \\
\hline 2 & $66,67 \%$ & 2,7 & & 19 & $3,33 \%$ & 1,39 \\
\hline
\end{tabular}

\begin{tabular}{|c|c|c|c|c|c|}
\hline 3 & $28,57 \%$ & 2,61 & 20 & $0,00 \%$ & 1,4 \\
\hline 4 & $12,50 \%$ & 2,55 & 21 & $3,70 \%$ & 2,01 \\
\hline 5 & $0,00 \%$ & 2,43 & 22 & $3,45 \%$ & 1,86 \\
\hline 6 & $0,00 \%$ & 2,53 & 23 & $6,90 \%$ & 1,02 \\
\hline 7 & $0,00 \%$ & 2,55 & 24 & $25,93 \%$ & 1,21 \\
\hline 8 & $16,67 \%$ & 2,53 & 25 & $13,79 \%$ & 0,97 \\
\hline 9 & $0,00 \%$ & 2,48 & 26 & $20,69 \%$ & 1,89 \\
\hline 10 & $0,00 \%$ & 2,5 & 27 & $4,00 \%$ & 1,1 \\
\hline 11 & $84,21 \%$ & 1,32 & 28 & $0,00 \%$ & 2,11 \\
\hline 12 & $88,89 \%$ & 1,48 & 29 & $2,86 \%$ & 1,87 \\
\hline 13 & $94,44 \%$ & 1,46 & 30 & $0,00 \%$ & 1,06 \\
\hline 14 & $94,74 \%$ & 1,44 & 31 & $2,50 \%$ & 1,03 \\
\hline 15 & $77,78 \%$ & 1,41 & 32 & $2,38 \%$ & 0,93 \\
\hline 16 & $93,75 \%$ & 1,4 & 33 & $0,00 \%$ & 1,08 \\
\hline 17 & $88,89 \%$ & 1,42 & 34 & $7,50 \%$ & 0,98 \\
\hline
\end{tabular}

Rata-rata tingkat keberhasilan membaca wajah pada tiap gambar sebesar $27,49 \%$ dengan rata-rata kecepatan yang dibutuhkan sebesar 1,74 detik. Untuk hasil percobaan dengan menggunakan metode Viola-Jones ditunjukkan seperti tersaji pada Tabel II.

Rata-rata tingkat keberhasilan mengenali wajah pada suatu gambar dengan metode Viola-Jones sebesar 28,25\% dan ratarata kecepatan yang dibutuhkan adalah 1,09 detik.

Beberapa objek tidak dikenali sebagai wajah jika posisi wajah menghadap ke samping lebih dari $60^{\circ}$, menunduk, atau melihat ke atas. Posisi wajah pada hasil yang menunjukkan presentase besar mayoritas diambil secara tegak lurus atau dengan sudut kemiringan maksimal sebesar $45^{\circ}$ dari depan. Metode Kanade-Lucas-Tomasi menghasilkan 85,86\% objek dikenali sebagai wajah pada kondisi tersebut. Metode ViolaJones menghasilkan $87,71 \%$ objek yang dikenali sebagai wajah. Bahkan ketika semua wajah tegak lurus menghadap kamera, presentase keberhasilan mengenali objek sebagai wajah bisa meningkat di atas $90 \%$.

TABEL II. HASIL PERCOBAAN METODE VIOLA-JONES

\begin{tabular}{|c|c|c|c|c|c|c|}
\hline \multicolumn{7}{|c|}{ Viola-Jones } \\
\hline Data & Hasil & Waktu & Data & Hasil & Waktu \\
\hline 1 & $83,33 \%$ & 1,89 & & 18 & $7,14 \%$ & 0,97 \\
\hline 2 & $83,33 \%$ & 1,97 & & 19 & $3,33 \%$ & 0,9 \\
\hline 3 & $28,57 \%$ & 1,76 & & 20 & $0,00 \%$ & 0,85 \\
\hline 4 & $12,50 \%$ & 1,78 & & 21 & $3,70 \%$ & 0,85 \\
\hline 5 & $0,00 \%$ & 1,75 & & 22 & $3,45 \%$ & 0,85 \\
\hline 6 & $5,26 \%$ & 1,71 & & 23 & $6,90 \%$ & 0,85 \\
\hline
\end{tabular}




\begin{tabular}{|c|c|c|c|c|c|}
\hline 7 & $0,00 \%$ & 1,66 & 24 & $25,93 \%$ & 0,88 \\
\hline 8 & $16,67 \%$ & 1,68 & 25 & $13,79 \%$ & 0,83 \\
\hline 9 & $0,00 \%$ & 1,65 & 26 & $20,69 \%$ & 0,84 \\
\hline 10 & $0,00 \%$ & 1,66 & 27 & $8,00 \%$ & 0,83 \\
\hline 11 & $84,21 \%$ & 0,76 & 28 & $0,00 \%$ & 0,89 \\
\hline 12 & $88,89 \%$ & 0,77 & 29 & $2,86 \%$ & 0,83 \\
\hline 13 & $94,44 \%$ & 0,78 & 30 & $0,00 \%$ & 0,85 \\
\hline 14 & $94,74 \%$ & 0,77 & 31 & $5,00 \%$ & 0,84 \\
\hline 15 & $77,78 \%$ & 0,75 & 32 & $2,38 \%$ & 0,73 \\
\hline 16 & $93,75 \%$ & 0,75 & 33 & $0,00 \%$ & 0,82 \\
\hline 17 & $88,89 \%$ & 0,77 & 34 & $5,00 \%$ & 0,71 \\
\hline
\end{tabular}

\section{SIMPULAN}

Penelitian ini menggunakan metode Viola-Jones dan Kanade-Lucas-Tomasi untuk mendeteksi wajah manusia, dengan tujuan mendeteksi wajah dengan berbagai posisi sudut untuk menghitung jumlah orang dalam suatu gambar. Ratarata tingkat keberhasilan di atas $90 \%$ pada sudut tegak lurus ke arah kamera. Untuk wajah menghadap samping hingga $45^{\circ}$, hasil dengan metode Viola-Jones menghasilkan presentase keberhasilan sebesar $87,71 \%$, sedangkan hasil dengan menggunakan metode Kanade-Lucas-Tomasi menghasilkan presentase keberhasilan sebesar $85,86 \%$. Waktu yang dibutuhkan untuk mengenali wajah dengan metode ViolaJones terbilang cepat, sekitar rata-rata 1,09 detik jika dibandingkan dengan metode Kanade-Lucas-Tomasi dengan rata-rata sebesar 2,07 detik.

\section{UCAPAN TERIMAKASIH}

Penulis mengucapkan terima kasih kepada Universitas Padjadjaran atas dukungan dana penelitian ini melalui Penelitian HIBAH PENGEMBANGAN KAPASITAS RISET DOSEN Tahun 2016. Terima kasih juga kepada sivitas akademika Unpad atas bantuannya dalam eksperimen.

\section{REFERENSI}

[1] N. Kar, M. K. Debbarma, A. Saha, and D. R. Pal, "Study of Implementing Automated Attendance System Using Face Recognition Technique," Int. J. Comput. Commun. Eng., vol. 1, no. 2, 2012.

[2] J. Savitha and A. V. S. Kumar, "Face Tracking and Detection using S-PCA \& KLT Method," Int. J. Adv. Res. Comput. Sci. Manag. Stud., vol. 2, no. 2, pp. 224-229, 2014.

[3] P. Viola and M. J. Jones, "Robust Real-Time Face Detection," Int. J. Comput. Vis., vol. 57, no. 2, pp. 137-154, 2004

[4] GlobalSecurity.org, "Biometrics." [Online]. Available: http://www.globalsecurity.org/security/systems/biometrics.htm.

[5] R. Munir, Pengolahan Citra Digital dengan Pendekatan Algoritmik. Bandung: Informatika, 2004.

[6] D. Putra, Pengolahan Citra Digital, 1st ed. Yogyakarta: Andi Offset, 2010.

[7] S. Nugroho, "Sistem Pendeteksi Wajah Manusia pada Citra Digital," Universitas Gadjah Mada Yogyakarta, 2004.

[8] I. Andrian, "Perbandingan Metode Viola Jones dengan Metode Roberts Cross pada Sistem Pengenalan Wajah," Universitas Komputer Indonesia Bandung, 2012.

[9] M. D. Putro, T. B. Adji, and B. Winduratna, "Sistem Deteksi Wajah dengan Menggunakan Metode Viola-Jones," in Seminar Nasional "Science, Engineering and Technology," 2012, pp. 1-5.

[10] H. Pratikno, "Kontrol Gerakan Objek 3D Augmented Reality Berbasis Titik Fitur Wajah dengan POSIT," JNTETI, vol. 4, no. 1, pp. 16-24, 2015. 